\title{
Creating Spaces Where Things Happen: The Life Story of a Business Anthropologist
}

\author{
Gordon Bronitsky \\ Bronitsky and Associates
}

I am a business anthropologist as well as the founder and President of Bronitsky and Associates. For the last 15 years, we have worked with Indigenous people around the world in the performing arts and festival development. In this short article I recount where I began, how I got here, and where I am going at the intersections of anthropology, business, Indigenous performers, and the performing arts.

\section{INTRODUCTION}

Anthropology is the holistic "science of human beings", which deals with the integration of different aspects of the social sciences. Anthropologists are those social scientists who study human beings and their behaviors within diverse cultural contexts. Business anthropologists are those anthropologists who study the business fields of management, operations, marketing, consumer behavior, organizational culture, human resources management, international business, competitive intelligence, knowledge management, and so on through anthropological perspectives. There are also business anthropologists who start and run businesses by applying anthropological theories and methods.

I am an anthropologist who has established his own business and who works with Indigenous peoples around the world in the performing arts and festival development. In this paper I will briefly present my own life experiences as an anthropologist in my own business practice.

\section{BACKGROUND}

I have a doctorate in anthropology from the University of Arizona (1977). I used to be an academic person. Recently, I had a long conference call with people in Rome about producing a Handel opera in Bhutan and I continued working on producing IndigeNOW! Indigenous Opera from Three Continents and Three Countries. The United States Embassy in Egypt contacted me about bringing a zydeco group to Cairo, and the United States Embassy in Ecuador contacted me about bringing Navajo artists and performers to Quito. It sure does not sound like anthropology to most anthropologists, but it does to me. Perhaps some explanation is in order. 
I am often asked how I got to where I am now, working with Indigenous people around the world in the performing arts (traditional AND contemporary) and festival development and goodness knows, I have asked myself that very question more than once--how DID I get here?! How did I end up creating spaces in which things happen? As always, it's best to start at the beginning.

I grew up in Albuquerque, New Mexico, a state with an American Indian population of about $10 \%$, one of the highest percentages in the US. I knew Indian people growing up, went to school with them, and worked with them. By the time I was 12, I knew I wanted to study about American Indians past and present - I wanted to be an archeologist. I wanted to be an archeologist so much that when I was in college at the University of New Mexico and had to choose a minor (my major was anthropology, of course!), I could not think of anything that interested me nearly as much as anthropology and American Indian studies, so I chose English as my minor, figuring I would have a head start, since I already spoke the language.

Then I went to graduate school at the University of Arizona, again in anthropology. The focus of the department was on the totality of the human experience so I studied all of the traditional four fields of anthropology-archeology, cultural anthropology, physical anthropology and linguistics. I focused on the archeology of the Southwest and Mexico but gained valuable experience in classes in other aspects of anthropology (a special thanks to Keith Basso in that regard) and in work projects (a shout out to Bill Rathje and the Tucson Garbage Project!).

$\mathrm{PhD}$ in hand in 1977, off I went. I taught at several colleges and universities as an archeologist and anthropologist, usually teaching courses in the all the basic fields and introduction to American Indian studies. I was on my way to tenure, a tweed jacket, and ivy-all the traditional accouterments of the professoriate. No marketing or business background for me. I was destined for academe.

And then two things happened which started me on the road to where I am now. In 1984-85, I served as a Senior Fulbright Professor at the Johan Wolfgang Goethe University in Frankfurt in what was then West Germany, at the Institut für Historische Ethnologie. It was the year that changed my life. My teaching area was American Indians, and I lectured all over Europe and Israel on a broad range of American Indian and archeological topics. In a sense, I saw the demand side of the equation of my future, and had a wonderful year.

Then in 1987-88, I was a professor in the Cultural Studies Department at the Institute of American Indian Arts in Santa Fe (www.iaia.edu), the only American Indian-controlled institution of education in the arts in the United States. I was amazed by the breadth of its offerings and the talent of its students-here I saw what could be termed the supply side of the equation of my future.

\section{STARTING MY BUSINESS: CREATING SPACES WHERE THINGS HAPPEN}

In all of these academic wanderings (at one point, I moved six times in nine years), I did not get tenure. I faced a choice-I could be an adjunct gypsy academic, teaching a course here and a course there, no hope of a future, living on my knees. Or I could move on. So about 1994, I decided to plunge full-time into what I had been doing on a small scale for a few years. I had done further lecturing in Europe about Indians. I had talked with many Indians about their work and their frustrations at the narrow limits of what "everybody knows" Indians do.

It took a while to figure out what to call it but I finally settled on the term, international cultural marketing. I did not want to just tour powwow groups, although I had sung with the Red 
Thunder Singers at UNM as an undergraduate and still the enjoy the music very much. I wanted to show the world the incredible depth and breadth of what American Indians were actually doing.

I was especially fortunate that, shortly after I decided to follow my dreams, I met the Chinle Valley Singers, a very accomplished and professional group of traditional Navajo Indian singers and dancers. Traditional Navajo music and dance are very different from what "everybody knows" Indian music and dance is--the flashy and individualistic music and dance of the Plains Indian powwow. Several people even told me I would never be able to do anything with them because they were not powwow--and because most of the members of the group were women. But Linda Davis, the leader of the group, told me they loved their music and were proud of Navajo music and dance, and they wanted to see the world. How could I refuse? As of today, I have toured them to Estonia, Latvia, the Philippines, England, the Netherlands, Italy and Dubai!

And I began to hear from more and more Indian performers, traditional AND contemporary-writers, theater makers, modern dancers, rock bands--the quality and diversity left me amazed. I kept wondering, why haven't more people experienced these powerful and dynamic performers, heard and seen their messages?

In other words, I had to develop a marketing perspective--what value can I create for customers and clients? It cast my anthropological experience into new and innovative perspectives and activities. Where most anthropologists seemed to focus on preserving traditional culture, I wanted to promote Indigenous performers.

\section{CORE PRINCIPLES}

I decided early on that my work would be based on two principles. One was a business principle, which I called "one-stop shopping"-whatever a venue would want, I would either know who did it or could quickly find out. This brought together my anthropological skills and knowledge together with a focus on customer needs a central tenet in marketing.

The second principle was more of a philosophical one. I was not Indian and never pretended to be one-I was happy being what I am. In my business, Native people would choose the message, whether that message was a traditional Navajo music group, a Navajo language writer, or an Australian Aboriginal rock band-and I have worked with all of these. My job would NOT be to tinker with the message, adding a feather here, a feather there. My job would be to CRANK UP THE VOLUME!

Call it buzz, call it reaching new segments - that's the heart of my business. And that is what I have been doing ever since, whether getting a Navajo writer published in Ireland in Navajo, English and Irish, touring a dance group from Zuni Pueblo to Mongolia, touring Mariachi Imperial to Armenia, and most recently, bringing Indigenous theater companies from Canada, the US, Australia and New Zealand onstage in London and now laying the groundwork to create an international Indigenous performing arts festival.

Early in my non-academic career, someone said of me that I "create spaces in which things happen"--and I still think that's the best description of what I do. Let us use ORIGINS as an example.

ORIGINS was an international Indigenous theater festival which premiered in London on May 4, 2009. I was the creator and Executive Producer--but the origins of ORIGINS go much further back. The seed was planted over 11 years ago. In 1998, I was living in Denver, Colorado, and saw a wonderful play, The Rez Sisters, by Canadian First Nations playwright 
Thomson Highway. I asked the director of the venue when we could see more plays by Native playwrights. He replied that his theater was now getting back to "serious theater"-no more Native plays or playwrights. Native playwrights, Native actors, Native messages and voices, some angry, some funny, some beautiful, some deliberately ugly, all powerful--NOT serious theater? I was outraged.

I began to look around. There were very few opportunities for the public to see Native playsa play here this year, a play in another state in a few years. It was much easier to write a dissertation on Native playwrights than to see their work. I thought this was a ridiculous situation.

I began to think about how to create an annual event with excellent production values and wide-ranging publicity, and began to talk to many people. Over the years, I became absolutely evangelical about my belief that Indigenous Theater deserved an annual event all to itself. Powwows and Native arts and crafts festivals certainly had annual events which showcased the best talent and drew large audiences. Why not theater? How could I create such an event, such a space in which Native theater could happen on a regular basis?

Over the years, I must have heard every reason why such events could not happen-no audiences, no playwrights (which I thought was a strange comment indeed), no Native theater companies, no money, no interested venues. I talked with anyone who would listen, wrote concept papers, drove to meetings and more meetings. Nothing. I started to despair.

In 2003, Michelle Broun, then with the Arts Council of Western Australia, brought me to Perth to speak at the Western Australia Indigenous Arts Showcase. It was a marvel of contemporary and traditional WA Indigenous talent-and it was there I met the artistic director of an organization in London which is dedicated to cross-cultural performance. He and I began to explore the possibility of an Indigenous theater event, e-mailing each other over the next several years.

In the course of many meetings about Indigenous Theater in New Mexico, I met David Velarde, a Jicarilla Apache playwright. The meetings went nowhere but I was impressed by his interest and determination, often driving 4 hours in each direction from his home town of Dulce in northwestern New Mexico for a meeting, and then driving back. In 2005 I had the opportunity to create a Native playwright's symposium in Edinburgh, Scotland. David liked the idea very much and participated, funding his own travel. This was my chance, I thought. I was unable to go, but I gave David a concept paper for an Indigenous theater festival and urged him to meet with the artistic director in London. They did, and that eventually led to ORIGINS.

We began to focus on an initial meeting of Indigenous playwrights. London was the obvious choice. The capital of the theater world, the heart of the colonial empire that had subjugated so many Indigenous peoples-where better than London to begin to hear Indigenous voices in theater? Names were proposed, dates and places discussed by e-mail and phone.

And finally in 2007, we had the ORIGINSTM launch, bringing the playwrights in the photoDavid Velarde, David Milroy (Australia), Trevor Jamieson (Australia), Harriet Nordlund (the Sami side of Sweden, as she always says), Rosanna Raymond, the artistic director, and myself. A week of workshops and discussions and good times ensued, learning about each other and our communities and our work, funded by the Arts Council of Australia, the US embassy and others, capped off by a reception at the Australian High Commission in London (to whom I will always owe a debt of gratitude).

We decided to embark on ORIGINS ${ }^{\text {TM }}$ as an international festival of Indigenous Theater from around the world-big dreams from a few people from many places gathered in London. I knew it 
would take time to create ORIGINS ${ }^{\mathrm{TM}}$ and we wanted to keep the momentum going, so I developed the concept of ORIGINS on the Road'T, which would bring Indigenous theater makers from around the world to Indigenous and non-Indigenous theaters and communities around the world. It would be relatively inexpensive to tour someone from one country to another but would enable us to begin to create the ORIGINS ${ }^{\mathrm{TM}}$ vision and give us a track record as well.

I have been trying to remember how David Milroy became the first to go on the road for ORIGINS $^{\text {TM }}$, but I just can't-did he volunteer? Was he pushed? I cannot remember but I decided I would tour David Milroy to the US in 2008. And what a wonderful, fun, exciting, educational experience that turned out to be! Contacting universities and tribal colleges across the US, soliciting funds from whomever would listen, I was able to bring David to the US in September 2008 for a 20 day road trip that Kerouac and the Beats would have loved. University of Minnesota, Sinte Gleska University (South Dakota), Oglala Lakota College (South Dakota), Little Wound School (South Dakota), Fort Berthold Community College (North Dakota), the University of Kansas, and Haskell Indian Nations University in Kansas-thousands of miles by car, workshops and presentations on David's life and people and theater for university playwriting students and 8th graders, for tribal audiences and theater folk, Mount Rushmore and Jewel Cave National Monument and so much more. An honoring powwow at Little Wound School, public thanks (and an exchange of a beaded Western hat and David's Aussie hat) from the Chairman and Tribal Council of the Federated Tribes of the Mandan, Hidatsa and Arikara at Fort Berthold, wide-ranging discussions about life and theater and jokes and sightseeing - it was an experience that I know I'll always cherish.

Since then I have toured David Velarde to a Sami playwrights conference in Sweden and Sami playwright Harriet Nordlund to the US, both as part of ORIGINS on the Road. At last, in May 2009, The London Maori community welcomed the ORIGINS ${ }^{\text {TM}}$ companies and the start of the inaugural season with speeches and traditional welcomes in The Scoop, a part of More London near London Bridge. After eleven years of thinking, dreaming, talking, working, planning and, of course, fundraising, the international Indigenous theater festival was happening! The initial performance for the inaugural season was the New Zealand company Taki Rua's production of Strange Resting Places, by Paolo Rotondo and Rob Mokaraka, directed by Leo Gene Peters, and featuring Paolo Rotondo, Rob Mokaraka and Maaka Pohatu.

Strange Resting Places traces the stories and personal experiences of the Maori Battalion in Italy during WWI during the Allied battle for Monte Cassino, Italy. Performed in English, Italian and Maori, Strange Resting Places tells the stories of the Maori and Italians caught up in the conflict and the aftermath-scary, hilarious, angry and more. I thought it was a powerful and moving production-a perfect start for eleven years of dreaming and working towards this moment. BRAVO!!!!!!! Derek Leask, the High Commissioner for New Zealand in the United Kingdom hosted a reception at the Soho Theater-a wonderful opportunity to finally meet the talented cast and director.

I had begun with anger and vision and despair. I had produced something beyond my wildest dreams. And I had learned more than I had ever imagined. I had learned that I could create events with contemporary Indigenous voices, could get them funded, could get them publicized, and audiences would be interested and attend. 


\section{THE FUTURE}

But where is all this leading? I turned 60 in 2009, and I have been in this business for fifteen years. I have been thinking a great deal about what I have accomplished, where I have been, and where I want to go.

Over the years, I have learned from experience that Indigenous artists and performers are almost always marginalized-there is one and only one Indigenous artist or performer at an event or festival, especially in the performing arts, especially for contemporary performers. This marginalization often traps performers, audiences and venues into the limitations of what "everybody knows" Indigenous people do, rather than opening all of us up to the power and diversity of what Indigenous people actually do. Yes, American Indian music certainly includes powwow and flute music-but it also includes chamber music and hip hop and heavy metal. Yes, some American Indian music is spiritual-but it is also loud, angry, funny, and much more.

But where can audiences (customers and societies in the anthropological realm) and booking agents and venues (in the marketing realm) go to listen to this music, see the range of Indigenous performance, hear Indigenous comedy? In conversation with American Indian artists and performers, I often say that if I asked them where I could hear the best powwow music, or see best arts and crafts, they could easily name ten places off the top of their heads. But if I was to ask where I could hear the best Indigenous hip hop, see the best Indigenous Theater, enjoy the best Indigenous fashion, the answer is often just a shake of the head-who knows?

But it's not because the fashion, the hip hop, the theater isn't there. It's because there is no place to experience international Indigenous performance on a regular basis. Yes, several countries now have festivals and events which regularly showcase the best in their countriesshoutouts to The Dreaming in Australia, Planet IndigenUS and Imagine + Native in Canada, Pasifika in New Zealand. These are all English-speaking countries and they have led the way. But what about Indigenous performance from Siberia? or Mexico? or Peru? Or the US?

As a result, I have decided that my goal now will be to create an annual Indigenous performing arts festival that will:

1. be partnered from the beginning with an Indigenous organization or community

2. showcase the best Indigenous performing artists from around the world-theater, modern dance, music, fashion, film/video, photography, written and spoken word

3. train Indigenous young people how to run the festival and, eventually, take it over

4. introduce Indigenous performing artists to the business-what is an agent? what is a contract?-since many people come from isolated rural and urban communities where this information is difficult if not impossible to find

5. eventually, serve as a performing arts showcase as well, introducing the best Indigenous performers to venues and booking agents from around the world

It's an exciting goal and one that needs to happen. I'm not sure I can make it happen, but I am sure I'll give it everything I have. Where to go from now on? 2010 is already even larger, bolder, and more exciting:

- Touring Mariachi Imperial de America to Albania and Macedonia under the auspices of the US embassies in those countries. 
- Touring the Maxwell Street Klezmer Band to Lithuania under the auspices of the US embassy there.

- Touring Inuit throat singer Lois Suluk Locke from Nunavut to Albuquerque and Santa $\mathrm{Fe}$, where they will be the first non-US citizens ever to perform at Indian Market.

- Serious discussions about producing the opera Acis and Galatea, by Handel, in Bhutan in 2012.

- The fundraising launch for IndigeNOW! Indigenous Opera From Three Continents and Three Countries, featuring composers Deborah Cheetham (Australia), Harriet Nordlund (Sami Sweden), Brent Michael Davids (USA) and Lyz Jaakola (USA).

\section{BUT WHAT DOES ALL THIS HAVE TO DO WITH ANTHROPOLOGY?}

After all the theories and articles and reviews and books, anthropology is the study of people. I have used anthropology and anthropological skills and expertise in many ways. Certainly it has helped me find answers to many practical questions--who are the Indigenous peoples of Siberia? How are they organized? What is their diverse history with Russians?

It has helped me in other ways, too. In dealing with members of Indigenous communities, when is it good for me to speak up? And when is it best for me to remain silent? And anthropology has been essential in a more general outlook, knowing the difference between the view(s) of a community from within, and the view(s) from outside--the emic/etic distinction of my graduate school years.

But more than that, anthropology has informed and shaped my business practice and my personal beliefs as well. Indigenous people are surrounded by well-meaning experts who "know all about them", full of advice on how they should deal with community problems, environmental problems and so much more. Anthropology has opened me up to many diverse Indigenous voices. And it led to my decision that my business would focus on "cranking up the volume" for these voices. As a result, in an economic climate where the market for academic anthropologists has collapsed, there is a booming market for applied anthropologists--the future looks great!

\section{ACKNOWLEDGEMENTS}

Mark Bergen, the James D. Watkins Chair in Marketing at the Carlson School of Management at the University of Minnesota offered much encouragement and a very thorough and helpful review of the initial draft.

My parents, the late Dr. Jacob and Hedy Bronitsky, were always excited, always supportive, always encouraging when I left the main road of anthropology to pursue my own trail.

The Talmud asks us, who is wise? And the answer is, he who learns from all people. Working together, learning from each other, encouraging each other, arguing with each other--I have been blessedly fortunate to have so many wonderful teachers over the years who shared their performances and messages with me. In this limited space, I can only thank the two who taught me the most, Linda Davis and Elsie Deswood of the Chinle Valley Singers. Ahéhé! 